\title{
THE NIGER DELTA PHENOMENON FROM THE PERSPECTIVES OF SARTRE'S EXISTENTIALISM AND SOCIAL POSITIVISM
}

Ncha Gabriel Bubu $\square$; Department of Philosophy, University of Calabar, Calabar, Cross River State, Nigeria

\begin{abstract}
To some, existentialism and positivism in bipolar thinking, are dichotomies, others view them as related concepts in philosophy. It is a considered view of this paper that these two schools of thought are re lated, complementary and have a relationship that is useful in conflict resolution. This assertion is examined in this analysis vis -à-vis the Niger Delta, is the trust of this paper.
\end{abstract}

Keywords: Existentialism, Positivism, Niger Delta, Sartre's Existentialism.

$\bowtie$ nchagabriel@ymail.com

Citation: Bubu, N. G. (2021). The niger delta phenomenon from the perspectives of sartre's existentialism and social positivism . Social Sciences, Humanities and Education Journal (SHE Journal), 2(1), 1 - 12. DOI: 10.25273/she.v2i1.8546

\section{$($ (c) $)$ EY-NC-SA}

Published by Universitas PGRI Madiun. This work is licensed under the Creative CommonsAttributionNonCommercial-ShareAlike 4.0 International License. 


\section{INTRODUCTION}

The beauty of philosophy is often seen in the ability of philosophers in manipulating and translating Ideas into practical and work-able programmes and applying them to solving human existential problems. This explains why in common philosophical parlance, philosophers are called sons and daughters of their own age. This means that particular trends of thought or philosophical systems are generated to address particular problems at particular historical epochs. Accordingly, the basic problems of a political theory are set by its age. (Irele 1993, p. 43). For instance, Plato and Rousseau were obsessed by intimations of corruption, disorganization and breakdown in the society (Nisbet 1983). This shows that the works of particular philosophers are actually shaped by happenings around them, the social, economic, political and religious mileau. According to Copleston (2010), Plato's philosophy was clearly influenced by the general cultural situation in which he was born and brought up. This may be why Collins, and Michael say that "the conditions of social life determine the contents of our consciousness" (1993, p. 4). Following this, existentialism and positivism came in response to the problems of their time and age. Soren Kierkegaard, known as the founder of existentialism, was disturbed by the hardship and turbulence which existence inflicted on individual human beings, and he moved to address this phenomenon through his existentialism. Similarly, Auguste Comte was moved by the idea of developing a science of sociology that could address the problems of the society using the right approach in explaining phenomena by the facts of human life, a negation of metaphysics and religious approaches and beliefs at that time. This, paper on the strength of the above is using the existential approach as a solution to the Niger Delta phenomena.

\section{THE NIGER DELTA REGION}

From the contents of the United Nations' Development Programme's Report on Niger Delta Human development, the Niger Delta region is defined as comprising the area covered by the natural delta of the Niger River and the areas to the east and west, which also produce oil (Dennis 2020). By this, the natural limits of the Niger Delta can be defined by its geology and hydrology. Its approximate northern boundaries are located close to the bifurcation of the Niger River at Aboh, while the eastern and western boundaries are around Benin and the Imo River, respectively. By this report, the area covers approximately 25, 900 square kilometers. However, the broader Niger Delta region, which includes all oil producing states or areas and others considered relevant for reasons of administrative convenience, political expedience and development objective, extends the land area to 75,000 square kilometres (UNDP Report, 2006).

Similarly, Agamuoh Paul, gives a historical definition where he sees the Niger Delta as a region situated along the south-south and south-East and southWest of Nigeria in West Africa. It is located on the Delta of the Niger and its environs stretching from the old Calabar Kingdom through part of the hinter land to part of the old Benin Kingdom. During the British colonial era, Niger Delta was known as the oil River protectorate until 1893 when its borders were expanded and renamed, the Niger coast protectorate. The name 'Oil River Protectorate' emanates from the fact that oil palm production was the major occupation of the people (Agomuoh, www.goggle.com. July, 2010).

The Niger Delta maintains an important position in Nigerian economy 
and of course forms the mainstay of the country's economy, the reason being, the crude oil that its produces in commercial quantity (Edet 2017). Oil was discovered in the Niger Delta early in the 1950s. Oil discovery was made in a town called Oloibiri in Ogbia Local Government Area of Bayelsa State. It was found in tertiary deposits at 12,000 feet below. The first commercial quantity was taken to international market on February 17, 1958.

\section{THE NIGER DELTA PHENOMENON}

Over the years, the Niger Delta region of Nigeria has been a scouldron and one of the hottest zones of the world, a fall out ironically of the discovery of oil in Oloibiri, a village in Ogbia Local Government Area of Bayelsa State in South-South geo $p$ political zone in Nigeria (Ncha, 2011; Enor 2007; Enor et al., 2019). The Niger Delta is blessed with abundant natural resources, specifically crude oil deposits found in on and offshore. Analysts say that the discovery of oil since 1956 in Ololbiri community in Bayetsa State, has been a blessing and a curse on the inhabitants. Some say it is more of a curse than a blessing. This means that oil which happens to be the mainstay of Nigerian economy ironically has caused more harm than good to the people from whose land it is mined. So what has come to be known as the "Niger Delta Problem/Phenomenon" originated from this. This problem has to do with the dissatisfaction of the people with the oil exploratory activities in that region which has caused untold hardship to the people in terms of underdevelopment, unemployment, environmental degradation, palpably pervasive poverty, exclusion from mainstream political participation before the election of President Goodluck Jonathan as Vice President and subsequently President. The attempt by the people of the region to resist this total disregard for the impact of ecological degradation has often landed them in serious conflict with the government who also wants to maintain its arguably legal authority over the resources (Aboh, 2014; Aboh, 2015; Aboh, 2019; Odey et al., 2019). The problem of militancy emanates from this, leading to tension, fear, and uneasiness that looms largely in the region (Ncha, 2010).

\section{POSITIVISM}

The term positivism is often associated with Auguste Comte, a French Philosopher who is known as the father or founder of positivism. However, the term was found or gleaned from the works of earlier philosophers such as William of Ockham, Francis Bacon, saint Simon etc, but it was Comte who popularized it as positive philosophy. Positivism is defined as a general attitude of mind, a spirit of inquiry, and as an approach to the facts of human existence (Stumpf, 1999). This positive philosophy was designed to ensure stability and progress in the society. For, Ozumba (2010), positivism means that which is useful, certain, precise, and connotes utility. It is a term that is anchored on order and progress. Edor, looks at the term as "the general notion that reality is governed by natural laws which are discoverable, by the simple use of reason that is the dialectics of induction and deduction" (2007, p. 85). Positivism has come to represent a wide spectrum of ideas regarding the scientific method. Positivism connotes a state of mind or attitude to the facts of human existence (Uduigwomen, 2007, p. 210). This implies that as humans our search for solutions to social problems must be free from theological and metaphysical notions and trappings but should be placed on concrete facts of existence (Collin, Michael, 1993, p. 26).

In other words, the search for knowledge must be in line with sensory data and perception. In this case, facts must be taken as observed without burrowing into the remote causes or essences that may be responsible for 
their existence. This is why Stumpf (1999), makes the point that scientific laws must be formulated on the basis of the constant relation of phenomena, which means that positivism involves description rather than explanation. To this end the idea of teleology and purposive nature is incompatible with positivism (Uduigwomen, 2007, p. 210). Classical positivism, associated with Auguste Comte, maintains that the human mind grows through three distinct stages namely, the religious stage, the metaphysical stage, and the positive stage. These are the stages that individuals as well as mankind pass through (Omoregbe, 1991, p. 9). Positivism posits that knowledge that is acquired scientifically is genuine and certain, and this is knowledge about observable phenomena. It therefore negates any knowledge that is not empirically gotten. This is the aspect of positivism that connects it to existentialism since existentialism places much premium on what is concrete and real and affects the individual directly. It is this understanding that we wish to explore within the context of the Niger Delta Region of Nigeria.

Social positivism: Social positivism is a type of positivism that is concerned and concentrates on man, society and problems within a given environment and focuses on the positive attitude of social life. It was formed by a French philosopher, Auguste Comte through the science of sociology which he prefers to call Queen of the sciences. This type of positivism claims that science is the only authentic and valid knowledge and that facts are the only possible objects of knowledge. This is the point where it has an affinity with existentialism, the philosophy that concentrates on concrete realities of human existence.

\section{EXISTENTIALISM}

Existentialism as a philosophical movement could be traced to the works of a Danish philosopher, Soren
Kierkegaard known as the father of existentialism. James Garvey and Jeremy stangroom, define it as "a philosophical approach and cultural movement that came to prominence in the middle part of the 20th century namely, that we are absolutely and radically responsible for all our actions" (2012, p. 296). Existentialism can also be seen as "any philosophy that asserts that the most important philosophical matters involve fundamental questions of meaning and choice as they affect actual existing individuals (Soccio, 2007, p. 404). In another perspective, Ozumba Godfrey (2001), views it from the angle of integrative reasoning in which he sees it as a method of arriving reality through self-consciousness. Similarly, Francis Lescoe (1974), defines existentialism as a type of philosophy which endeavours to analyze the basic structures of human existence and to call individuals to an awareness of their existence.

It is important to state that these basic structures also embody Sartre's version of existentialism which is the concern of this paper. Basically, existentialism may be seen as an attitude, manner or outlook. In this connection therefore, Harold Titus, views it as "an attitude which emphasizes human existence and the qualities which are distinctive in individual person rather than man in the abstract or nature and the world in general" (290). It is germane to point out that this attitude focuses on the concrete human condition and this in itself constitutes the reflector for all existentialists .For the existentialists, a negation of this human condition, could be very devastating to any existing government, because it could cause civil and violent uprising like the ones in Tunisia, Egypt, Libya and the ongoing civil uprising in Syria. This is the attitude that gave rise to the existential themes of dread, boredom, alienation, the absurd, Freedom, commitment, and nothingness etc.

The term itself is associated with notions like depersonalization, 
dehumanization, objectification and Thingification used by many existentialists. These notions are understood in relation to the usefulness or worth of man in terms of his social roles functions, position and relevance in the society. When these words are applied to man negatively, we find that man is reduced to nothingness and in this case excluded from the scheme of things and is considered as one that does not matter (Ncha 2012). Some major existentialists include Soren Kierkegaard, Jean Paul Sartre, Martin Heidegger, Karl Jaspers, Gabriel Marcel, Albert Camus, and Maurice Marleau Ponty. From which ever angle one approaches existentialism, one thing that cannot be divorced from and which constitute the bone marrow of existentialism, is the fact that it is concerned with the basic facts of human existence. Following this, the popular dictum of this movement is "existence precedes essence". This is the point of understanding among different strands of existentialism (Ncha 2011).

\section{Sartre's Existentialism}

Having known the meaning of existentialism and positivism on the periphery, it is germane to briefly explain what Sartre's existentialism is all about before looking at Sartre's existentialism and positivism vis-à-vis the Niger Delta. This is both logical and ground clearing for useful comprehension.

Jean-Paul Sartre was a French existentialist, born in 1905 in Paris and spent a good part of his life there. Existentialism began with Soren Kierkegaard in Demark, but it was Sartre who actually gave existentialism its correct stamp, hence he is often called the apostle of existentialism. Indeed, Omeregbe Joseph, says that Sartre brought existentialism to its highest and popular point or level such that his name became synonymous with the term (1991, p. 87). Following this, Francis lescoe, echoes "it is no overstatement to say that, without qualification whatsoever, that the best known existentialist today is Jean-Paul Sartre (1974, p. 6). Sartre is said to be the one who brought the inner organs of existentialism outside for proper examination by way of highlighting the ideas of other existentialists in a most succinct manner (Ncha 2011). Oyeshile (2001) describes him as the legitimate heir of the existentialist revolt against traditional philosophy. Simply, Sartre's was a thorough going atheistic existentialist, which has zero tolerance for rationalism.

Sartre's existentialism is an atheistic existentialism which is based on the basic principle of existentialism given as "existence precedes essence". This serves as a Scaffolding for explaining the existence of man through the concrete realities of the universe. This very principle of Sartre is a negation of the old principle propagated by traditional metaphysics of the ancient period from Plato's writings, which posits that "essence precedes existence". Sartre's principle also upturned Heidegger's position/intentions of arriving at that elusive "Being of Beings".

Sartre position above became necessary so as to form a solid foundation for his atheism which rejects God and human nature. In his "existentialism is a humanism", he says.

"Thus, there is no human nature, because there is no God to have a conception of it. Man simply is, not that he is simply what he conceives himself to be, but he is what he wills, and as he conceives after already existing - as he wills to be after that leap towards existence. Man is nothing else but that which he makes himself" (1969, p. 291).

It is the direction or focus of Sartre's existentialism that makes it relevant to human existence because it attempts to liberate man from the clutches of human predicament by being 
creative in survival techniques. Sartre existentialism is heavily characterized by individual subjectivism. Man has no human nature, and therefore, can step out to arrange for himself anything he wishes, making himself different from a stone, chair or other objects because he possesses human dignity by the fact of his subjective life. Man, according to Sartre is a being that has the capacity to move himself towards a future and is conscious that he is doing so.

Sartre's existentialism is characterized by two modes of existence, or modes of being, that is two anthetical modes or ways of being, These modes of being are captured in his idea of Being for itself (L'être Pour-soi) and Being, initself (L'etre en-soi).It is germane to point out that if we relate this distinction to man, the implication may be that man shares both these two modes of being, in one showing that he is just like a stoneensoi, while the pour-soi indicating that he is a conscious subject which is a distinguishing feature that makes him different from a stone. Furthermore, to be a conscious subject, is to be placed constantly before a future. This means that the consequences of existence coming before essence, means that man not only creates himself but that the responsibility of man's existence rests heavily on him.

Again, these modes of being are associated with consciousness and unconsciousness. To this end, Being-for-itself is the being of consciousness which is associated with man. Other entities outside man are identified and denoted by the Being-initself which is the unconscious being. The Being-for-itself as consciousness of an object, is also associated with nothingness, emptiness, and negativity, Sartre puts it this way "Nothingness can be nothingness only by nihilating itself expressly as nothingness of the world, that is in its inhalation it must direct itself expressly towards this world in order to constitute itself as refusal of the world. Nothingness carries being in its heart" (Sartre, 1993, p. 18).

These features of the for-itself constitute the very foundation for man's struggle and suffering in the world. The reason being that man is always in the process of transcending this ugly situation, in order to negate this emptiness and nothingness so as to perhaps reach a fullness. Man is not a totality but is always in the process of totalization. It becomes clear hear that the Being-for-itself becomes being simply by negating being through separating itself from it and placing itself away from it. So, the for itself is a being of nothingness because nothingness constitutes its very essence (Sartre, 1993, p. 18).

Furthermore, the conscious being always experience a gap, a vacuum, an emptiness and nothingness, which the for-itself attempts to fill by negating itself. This shows, that the incomplete nature of man brings about the senselessness of his existence and this strives to accomplish the project of selffulfilment, a process of totalization which ironically cannot reach a totalization because man is not and cannot be a totality. He is always in a state of becoming and potency, which shows that being is meaningful at that level of the for itself.

Also, Sartre (1993) says that this transcendence of the Being for itself is made possible by the tool of human freedom with its heavy load of responsibility. Thus, the Being-for-itself cannot have a steady identity and cannot be captured in anything in any permanent manner. The entire existence and happenings of the for-itself constitute a mammoth project for it to conquer nothingness and emptiness which negates itself consistently. So, the Being-for-itself is not what it is and is what it is not. This shows that nothingness cannot be overcome since it is the very foundation of being and negation comes from nothingness. This means that the reality of the individual 
human being is possible by a perpetual negation of being.

In contrast to the Being-for-itself, the Being-in-itself does not have nothingness and negation within its being. It cannot have anything other than itself; it is simply there and full of itself and nothing more. Following this, the Being-in-itself is incapable of becoming something else other than itself. It is itself indefinite, and exhaust itself in being. It does not lack and therefore needs no association with the other, it is what it is and is subject to temporality Sartre explains further.

It is important to state that the Sartrean idea of polarized beings could be used in explaining most actions of man, and man's struggle and conflict in life could be discerned from the totalization process of the Being-foritself. Sartre's Being-for-itself is man conscious of the environment, and this is the basis for social consciousness. Our concern in this paper is the problems of existence in the Niger Delta, arising from the issue of consciousness and understanding. Here we are applying these features of Sartre's existentialism and social positivism to address the Niger Delta existential problems which reflect the action of the Being-for-itself and its consciousness of the regions poverty and negligence. Oshita, explains it in this manner, "the conflict in the Niger Delta could be a denial of the ontological needs of the people, and complicated by communal content, governance of the people, and international linkages. It transcends the conception of simply as the fear of the past lived in the present, it is an engrained and habitual consciousness of deprivation" (2007, p. 246). What this means is that this consciousness of the Being-for-itself is determined not by external causes, but it is rather bursting with spontaneous freedom and lives its life in terms of future possibilities (Lawhead 2003, p. 547). In this connection therefore, the trouble situation in the Niger Delta arises basically as a fall out of the consciousness of the people about the devastating effects of oil explorative activities and their efforts to negate this negation in order to attain a level of sanity.

\section{APPLYING SARTRE'S EXISTENTIALISM AND SOCIAL POSITIVISM TO THE NIGER DELTA PHENOMENON}

It is germane to point out here that positivism is related to existentialism not in terms of being a scientific method as conceived by Comte, but as a means of social engineering that concentrates on the bare facts of human life in a social environment. It is this aspect of it that Auguste Comte, a French philosopher, and first to coin the term, transformed into the science of sociology which he sees as the Queen of all sciences. From here, we derived the term social positivism as that which is basically concerned with man, society and problems within a given environment.

The confluence point of Sartre's existentialism and positivism is their concern with positive attitude of social life using the facts of human existence. The individual in the social gathering becomes the focal point if social problems must be solved. That is in resolving issues or social problems, we must consider the individual as the fulcrum that turns out the solution. We must make use of the individuals' concrete realities, the facts of human existence instead of seeking solution in things outside the individual within a social setting. This is in line with Kierkegaard's call on individuals to live authentic, passionate and honest lives, repudiating the temptation to find out meaning and identity in institutions or abstractions (Lawhead 2003, p. 637). It is in this that the application of Sartre's existential positivism could go a long way in resolving the Niger Delta conflict, and other conflicts around the world.

The Niger Delta problems have proved a hard nut to crack because, attempts to find a solution were devoid of Sartrean perspective which looks at 
the fundamental issues as they affect the region. The government of Nigeria has been concerned with finding a solution from the theoretical and rational angle without taking appraisal of the concrete facts or realities of the region in terms of the challenges of underdevelopment in the region that led to the conflict and security problems. Sartre on the contrary posits that in solving issues of human concern, we do not need to go into explanations but face the music as it comes by dealing with the concrete existential realities.

According to Sartre's existential positivism, any attempt to solve problems from a purely objective angle may not be efficacious. We must note that underlying every objective claim is a personal judgement. One of the problems we have in social science is that the subject matter is of an unstable nature. In explanation of subjectivity in social enquiry, Ozumba, strengthens this in his view that "the behaviour of man is so elusive, subtle and complex that it cannot yield to rigid categorizations and artificial instruments of science" (2010, p. 71). Following this, one cannot rely on any other thing other than man and his environment in solving social problems. Sartre's existentialism is concerned with this positivist behaviour in terms of appraising facts of existence as they are, and attempting solutions based on such. Sartre's approach does not look beyond the individual humans that make the society in a meaning making enterprise.

The government's attitude of using military option, pumping money to selected individuals, selective security to oil workers and government functionaries, non-release of funds for projects execution, and rationalization of the necessity of oil technology amounts to ignoring the concrete realities on the ground, and assuming a position that negates the spirit of existential positivism of Sartre. For instance the present government of Buhari, has only paid lip service to the issue of clean-up of oil spillage in the Niger Delta, among other problems. This claim is strengthened by the Pan Niger Delta Forum (PANDEF) and the United Niger Delta Energy Development Security Strategy (UNDEDSS) while x-raying the Niger Delta economy after the covid-19 lockdown, urged the Federal Government to do more for the Niger Delta region to alleviate the suffering of the people and to compensate them for the regions enormous support to the government. This appeal is captured by the following statement: "our appeal is that the dry dock-located in Lagos waters-be moved permanently, installed and inaugurated in Delta, considering the contributions of the region to the nation's economy" (Daily Sun, 2020, p. 6). Similarly, Uranta's comment gives credence to the claim of negligence by the federal government when he says "in a sense, the Federal Government seems to have forgotten the Niger Delta. I used the word "forgotten" because the Federal Government is basking in a false sense of euphoria that makes them relax their need to pacify or encourage positive actions and reactions in all the zones of the country but especially the Niger Delta" (Daily Sun2020, p. 13). From the above, we can see that Sartre's message of commitment, and responsibility are inescapable and are so defined by risk. This in a nutshell, constitutes the existential demand on the Nigeria government. It is an imperative to look and go back to the things themselves, and in doing so, must take a personal and subjective approach as an individual country rather than looking up to other countries for solution.

From Sartreen existentialism, we understand that man is a moving being. The Being-for-itself, conscious of the environment, is always moving and adjusting to the harsh life situation. The "for-itself" denoted by the individual, the Niger Delta, is in the process of actualizing itself by taking a positive attitude of life instead of relying on destiny. Sartre's existential positivism points out to the government that, the 
government's attitude and activities, its relationship with the multinational oil companies, constitutes "Nothingness", which must be overcome, hence the seeming endless resistance in the Niger Delta region. Sartre cautions that the individual in the Niger Delta is outraged by every mode of thinking and behaviour that dehumanizes him, levels him, and renders him anonymous or robs him of his supreme worth in existence. Thus, the individual in the Niger Delta is always in a process of overcoming this negation. Resistance fighters in the Niger Delta are aware that they are making free choices, and because they are under pain of death, each hour of each day demands that they create alternative ways of surviving.

Sartre says that no matter how difficult the choices, an individual experiences the deepest and most satisfying freedom in the very act of choosing. Every choice, he says, presents an opportunity to reaffirm the authentic self and achieves nobility in the face of tragedy.

To resolve this problem therefore, existential positivism requires that the 'Being' in the Niger Delta realizing that he is thrown into the world of environmental and social calamities without demanding to be there, is faced with social hazards and the challenge of defining himself through constantly making fundamental choices. He must constantly renew and affirm his identity by recognizing his uniqueness and selfresponsibility for his actions and inactions. For Sartre, the Being-in the Niger Delta lives authentically by not resorting to condescend to a level of inauthenticity by hiding under the "individuals writ-large" the government, state, public self-identity. This is impersonal identity. These ore abstracts opposed to positivism.

The individual writ-large (the Nigerian state) on her side, an entity, must be conscious of its social responsibilities and adopt a positive existential attitude towards social engineering so as to build a sound and useful region and the society at large (Eyo 2019a; (Eyo 2019b). This is the demand of social positivism. Government as an individual country, must be conscious of the facts of social life and must constantly appraise and make policies and decisions on government programmes that give priority to the human person with a view to ameliorating the human existential problems.

Sartre's existentialism sees success in terms of the individual understanding and achievement in life from improved environment for sustainable development and peaceful coexistence in which the individual is the architect. Any peace effort therefore, in the Niger Delta, must involve all the stakeholders who are subjectively committed to the course of peace and stability by first taking an assessment of the "self" and move consciously towards the other. Existential positivists are concerned with changing situation based on facts of life and that philosophy is useful if it is directed to the development of the individual and the society.

Existential positivism demands that the Federal Government must recognize that the causes of the Niger Delta problem are man-made and solution lies in man and nothing else. It requires government to therefore, negate this situation by applying an attitude of commitment through change, authentic and positive choices and responsibility. Sartre's philosophy posits that the government takes urgent decision and choice, particularly on the issues of oil revenue sharing formula and addressing the developmental challenges. That putting off a fundamental decision to address the issues and concrete realities on ground instead of rationalizing such, may be making a decision by default. Existential positivism demands that issues that underlie a conflict must not be rationalized but must be appraised as they appeared and in relation to the 
parties involved, that is sensory data must be fully explored and the facts and concrete realities should be taken into cognizance and fundamental decisions taken. The position of the being-for-itself in this circumstance becomes very relevant, and this way, conflict resolution is achieved and thus paves the way forward.

\section{CONCLUSION}

The Niger Delta phenomenon is an existential problem occasioned by the devastating effects of oil productive activities around the region and the nonchalant attitude of the government to the plight of the indigenous inhabitants of the area. In existential parlance, an individual-feels abandoned when he perceives or experiences an absence of meaningful relationship between his status, his identification, his social relationship, his style of life, work and the world, government and authority around him or her. Ucheaga Dorathy, maintains that "man is essentially a social being and realizes himself in the objective condition of his existence" (2001, p. 37).

Our aim in this work has been to examine these existential conditions from the perspective of Sartre's existential positivism. Sartre's existential positivism negates and sees as nothingness and emptiness, the devastating oil exploratory activities of the multinationals, and should therefore, be transcended. The existential condition of the individual in the Niger Delta must be emphasized because this is the basis, the fundamental factor, and facticity of existence that underlies any problem of existence. We are therefore, convinced that existential positivism of Jean-Paul Sartre could be a panacea to this problem.

\section{REFERENCES}

Aboh, J. A. (2014). Conflict management: A panacea to development. Sophia:
An African Journal of Philosophy, 14(2), 64-67.

Aboh, J. A. (2015). Assassinating political opposition: An" Albatross" and aberration-the Cross River example. Sophia: An African Journal of Philosophy, 16(1), 211215.

Aboh, J. A., \& Effiong, E. N. (2019). A Historical Periscope of Self Inflicted Socio-Political Predicaments of Nigerians.

Agamuoh, P. (2010). "History and Origin of Niger Delta". www.goggle.com.July2010.

Collins, R., Michael M. (1993). The Discovery of Society. New York: McGraw-Hill.

Copleston, F. (2010). A History of Philosophy: Logical Positivism and Existentialism. New York. Continuum.

Daily Sun. Wednesday May 27, 2020,

Dennis, O. (2020). Ethics of Posterity for Environmental Development of the Niger Delta. GNOSI: An Interdisciplinary Journal of Human Theory and Praxis, 3(3), 83-96.

Edet, A. (2017). Security Agents In Nigeria Sea Ports: A Focus On Port Harcourt Sea Port. Global Journal of Applied, Management And Social Sciences, 13.

Edor, J. (2007). "Positivism and Logical positivism: An Analysis" Philosophy, Education, Science and Technology, eds. Samuel A. Ekanem, and Joseph N. Ogar. Calabar. Samrol Publishers, 2007.

Enor, F. (2007). The Nta and Their Neighbors: Inter-group Relations in the Central Cross RIver Region. Jochrisam Publishers.

Enor, F. N., Magor, S. E., \& Ekpo, C. E. (2019). Contending Perspectives and Security Implications of Herdsmen Activities in Nigeria. International Journal of Research-GRANTHAALAYAH, 7(7), 265-286.

Eyo, U. E. (2019). Between Religion and Agriculture: A Roadmap to 
Revamping

Economy. GNOSI:

Nigeria's

Interdisciplinary Journal of Human Theory and Praxis, 2(1), 62-70.

Eyo, U. E. (2019). The Parable of the Talents and Economic Management: Lessons for the Nigerian Nation. GNOSI: An Interdisciplinary Journal of Human Theory and Praxis, 2(2), 55-63.

Garvey, J., and Stangroom. J., (2012). The Story of Philosophy: A History of Western Thought. UK: Quereus books.

Harold, T. (1957). Living Issues in Philosophy: An Introductory Textbook. New York: America Book Company.

Irele, D. (1993). In the Tracks of African Predicament: Philosophy and Contemporary Socio-economic and Political Problems of Africa. Ibadan: Options Books and Information services.

Lawhead, W. I. (2002). The Voyage of Discovery: A Historical Introduction to Philosophy. Belmont: Wadsworth.

Lawhead, W. I. (2003). The Philosophical Journey: An Interaction Approach. New York: McGraw Hill.

Lescoe, F (1974). Existentialism: With or without God. New York: Alba House.

Ncha, G. B. (2010). Oil Politics, Sustainable Amnesty Programme, and Sartre's Existential Philosophy" An Academic Journal of InterDisciplinary Studies. 1(2).

Ncha, G. B. (2011). Existential Justice: Integrative and Humanistic Perspectives. Journal Of Integrative Humanism Ghana, 1.

Ncha, G. B. (2012). The Problem of Militancy in the Niger Delta. The way out" Nigeria: Citizenship Education ed. G. O. Ozumba, et al Aba: Vitalis Books.

Nisbet, R. (1983). The Social and Political philosophers: Community and conflict in Western Thought. Washington: Square press, 1983.
Odey, J. S., Ajor, J. O., \& Aboh, J. O. (2019). The Place of History in Mitigating National Challenges: The Case of Nigeria. International Journal of Recent Innovations in Academic Research, 3(3), 23-31.

Omeregbe, J. (1991). Simplified History of Western Philosophy: Contemporary Philosophy. Lagos: Joja Educational Research and publishers Limited.

Oshita 0. 0. (2007). "Resources and conflict: A case Analysis of Niger Delta" Conflict Resolution, Identity crisis and Development in Africa eds. Celestine, Bassey and Oshita OShita. Lagos: Malthouse press.

Oyeshile, O. A. (2001). "Freedom and Human Value in Sartre's Existentialism: An Appraisal". Sophia: African Journal of Philosophy. 6(2).

Ozumba, G. O. (2001). The philosophy of Logical Positivism and the Growth of Science. Calabar: Bacos publications.

Ozumba, G. O. (2010). Philosophy and Method of Integrative Humanism. Calabar: Jochrisam publishers.

Sartre, J. (1969). Existentialism is a Humanism. Reprinted in Walter Kaufmann, Existentialism from Dostoevsky to Sartre. New York, the World publishing Company.

Sartre, J. (1993). Being and Nothingness. Trans. Hazel E. Barnes. London: Rutledge.

Soccio, D. (2007). Archetypes of Wisdom: An Introduction to Philosphy. Belmont: Wads-worth

Stumpf, S. E. (1999). Socrates to Sartre: A History of Philosophy. McGraw-Hill.

Ucheage, D. N. (2001). "Social Justice in Nigeria: The Dialectics of ideas and Realities" Humanities Review Journal. 1(2).

Uduigwomen, A. F. (2007). Textbook of History and Philosophy of Science. Aba: Vitalis books.

UNDP. Niger Delta Human Development Report. United Nations Development Programme. UN 
Bubu, N. G.

SHE Journal

House Diplomatic Zone, Abuja, Nigeria. 